Article

\title{
Examination of Individual Preferences for Green Hotels in Crete
}

\author{
Alexandros Apostolakis ${ }^{1, * \mathbb{D}}$, Shabbar Jaffry ${ }^{2}$ and Markos Kourgiantakis ${ }^{1}$ \\ 1 Department of Business Administration and Tourism, Hellenic Mediterranean University, \\ 71004 Heraklion, Greece; mkourg@hmu.gr \\ 2 Department of Economics and Finance, University of Portsmouth, Portsmouth PO1 2UP, UK; \\ shabbar.jaffry@port.ac.uk \\ * Correspondence: aapostolakis@hmu.gr; Tel.: +30-2810-379621
}

Received: 20 August 2020; Accepted: 28 September 2020; Published: 9 October 2020

check for updates

\begin{abstract}
The hospitality sector is experiencing a massive transformation currently. Hotels are currently receiving considerable criticism over their practices concerning energy, environmental, as well as resource management. As a result, managerial practices in the hospitality sector have come under scrutiny. All these developments have given rise to the concept of the 'smart' hotel. The smart hotel concept has received considerable attention in the relevant literature in the last few years. However, the majority of this attention has either focused on the technical side (i.e., examining smart hotels from a technological standards perspective), or adopted a rather limited perspective, choosing to focus on specific managerial practices within smart hotels (i.e., environmental management). The current paper aims to address this gap in the literature through the utilization of stated preferences discrete choice modeling methodology. Through this methodology, the paper evaluates tourists' preferences for a wider range of managerial practices and policies pertaining to smart practices in the hospitality sector. According to the empirical findings, tourists exhibit strong and negative preferences towards the automation of the service delivery process. In addition to that, respondents were very strongly opposed towards hotels without international certification standards for their operations. On the opposite side, tourists expressed very strong and positive preferences towards water management policies (particularly policies aiming to reduce and reuse water resources). Finally, respondents exhibited strong and positive preferences towards different energy-saving technologies within hotels.
\end{abstract}

Keywords: discrete choice modelling; Crete; smart hotels; willingness to pay

\section{Introduction}

One of the most recurrent themes in the tourism and hospitality literature during the last five years or so has been the concept of smart tourism and smart hotels [1-5]. This rise in popularity for the smart hotels concept is driven partly by an increasing concern for the environment and energy usage [6], caused partly by technological advancements [2,7], and partly by a changing consumer paradigm [1,8]. The principal argument underlying this theorizing is that hotel managers and practitioners alike could employ technological innovation in order to offer tailor made and customized service provisions to their customers (actual and hypothetical ones) [2,9]. In addition to the abovementioned factors, the smart tourism hotels concept has been used extensively in the literature to emphasize a destination's competitiveness in the market $[7,10]$. Hence, for destinations and hotels with a strong emphasis on mass tourism and price competitiveness, the notion of coming across as 'smart' is of imperative significance.

However, after this initial interest in the smart hotel tourism concept, one major issue has started to emerge in the relevant literature. Although much has been written in the literature in the past, 
there is yet to appear any concrete evidence in the tourism system. In other words, despite the popularity of the smart hotels concept, there is no evidence regarding the impact the concept exerts on consumers' preference patterns [4,11]. One would imagine that considering the significance and popularity of the concept in the literature, there would have been considerable effort to evaluate tourists' preference patterns for it. The argument is that the more hoteliers, practitioners and hospitality managers know about how tourists perceive smart hotels, the more apt they would be to use it to expand their competitive edge over other incumbents [2,9]. Thus, considering all the abovementioned observations, there is an imperative need for an evaluation of tourists' opinions regarding the smart hotels concept and how its various component parts influence individual preference patterns.

Correspondingly, the aim of the paper is to evaluate individual preferences for 'smart hotels' in the island of Crete, Greece. Accordingly, the objectives of the paper are set twofold. On the one hand, the paper elicits tourists' preferences for 'smart hotels' and translates them into policy initiatives to inform policy making by practitioners, managers and hoteliers in the field. Implicitly, hotel managers, practitioners as well as investors should pay more attention towards those product and policy configurations that guests' report the highest satisfaction or utility levels. This is at the forefront of evidence-based policy making in tourism. According to the literature, evidence-based policy making is of crucial significance for tourism development and competitiveness [12]. On the other hand, the paper utilizes a novel methodology (stated preferences discrete choice modeling) that allows the translation of individual tourist preferences into monetary values (through willingness to pay estimates).

One important area in the tourism and hospitality literature is the investigation of the factors that influence the selection of hotel accommodation by guests, as well as their willingness to pay for hotels rooms with specific attributes. Many studies around the world have investigated the key attributes which affect guests' hotel selection $[13,14]$, while other researchers have tried to connect the key hotel attributes to pricing issue $[15,16]$.

The adoption of environmental and information technology practices by the hospitality industry is recently studied as a significant factor that influence guests' preferences. Indicatively, several researchers $[17,18]$ explored consumer preferences and behavior towards green (eco-friendly) practices in the lodging industry, while reference [19] reviewed and analyzed more than 100 published research papers between 2009 and 2013 in order to provide a comprehensive overview of the applications of information and communication technology (ICT) in tourism and hospitality from the perspectives of both the consumer and supplier.

This research examines tourists' preferences and their subsequent choices for smart hotels in the Greek island of Crete. For the purposes of the current study, the definition of "smart hotel" is extended in order to include not only ICT practices, but also environmental technologies and policies adopted by hospitality industry. This extended definition could not be considered as arbitrary since (a) beside ICT it includes more technological innovations to the "smart" idea, and (b) the evolution of applied green or ecological applications in hospitality sector is enhanced by the ICT (e.g., the temperature or lighting setting in a smart hotel room is based on, or combined with, broader ICT technology).

Crete is a traditional mass tourism destination, with strong seasonal patterns of arrivals. Considering the fact that the tourism and hospitality sector is one of the top net contributors to regional and national gross domestic product (the contribution is estimated at about $11 \%$ of national GDP), it is apparent that maintaining the competitiveness of the sector is of paramount importance to everyone involved in the industry. Identifying as closely as possible consumer preferences and the factors that affect choice patterns in the tourism and hospitality sector could allow managers, practitioners and decision makers to offer a more customized and individualized service to visitors and guests. In turn, this could lead towards a more differentiated and unique service provision, distinctive of that of many other competitors.

Being an archetypal sea, sun, and sand destination [20], hotel managers and hoteliers in Crete are starting to invest into smart hotels for three main reasons. Initially, hotel owners are utilizing smart 
hotels in order to minimize and cut back on their energy costs, and at the same time appear more environmental conscious [21]. Second, they invest in smart hotels as a means to differentiate their offering from other close competitors [22]. Third, they perceive this as a way to respond to a changing business environment (pressures from Airbnb as well as changing consumer preferences) [21].

\section{Materials and Methods}

The current paper adopts a stated preferences discrete choice modeling (SPDCM) methodology to elicit tourists' individual preferences for future or/and hypothetical developments in the context of 'smart hotels'. The SPDCM methodology provides useful insights on the evaluation of respondents' (tourists') preferences, while also providing direction for future decision making to managers and practitioners in the area alike. To the authors' knowledge, the current study is the first attempt to utilize SPDCM to elicit individual preferences for smart hotels in the literature. In this respect, the methodology fits the purposes of the current study twofold. On the one hand, the adoption of the SPDCM methodology addresses recurrent and recent calls in the literature for engaging visitors and tourists even more in the decision-making process [23,24]. Recent studies in the field [25] have strongly criticized the fact that developments concerning smart hotels do not involve visitors and tourists in the decision-making process. Hence, the adoption of the SPDCM methodology would allow the hospitality industry to adopt a more customer-oriented rationale for the optimal use of hospitality resources [26].

The SPDCM methodology theoretically belongs to the suit of ex ante preference elicitation methods. It is very well suited in eliciting preferences for products and services that are hypothetical in nature, or have yet to appear in the market. The SPDCM methodology is founded around two basic theoretical pillars. It draws from Lancaster's characteristics approach [27], and random utility maximization theory [28]. The random utility maximization theory argues that individual consumers "have market behavior generated by the maximization of their preferences" [29] (p. 278).

On the other hand, Lancaster's characteristics approach implies that every product (future, of hypothetical) can be described on the basis of a number of characteristics, or attributes. Each one of these product characteristics, or attributes is then described through four configurations, or levels. Each one of these levels describes different states of the product in question. The first level (base) represents the current state of the world, whereas the remaining three represent future and/or hypothetical states of the world (either improvements or deteriorations from the current case scenario or 'status-quo').

The elicitation of individual preference patterns for alternative 'smart hotel' configurations was based along seven attributes. These attributes were, namely:

- Check-in/Check-out policies;

- Hotel room ambience technologies;

- Hotel's energy-saving technologies;

- Hotel's environmental policy certification standards;

- Hotel's waste management policy;

- Hotel's water management policy;

- Price.

Following $[30,31]$ recommendations, these choice modeling $(\mathrm{CM})$ attributes were selected following extensive research on the tourism and hospitality literature in the relevant field, round table discussions with industry experts and professionals, as well as a pilot study performed prior to the main study over a small sample of 50 individuals.

Table 1 below, summarizes the product attributes and their levels. Level 1 of each product attribute represents the current situation (usually this with the lower standards) and takes the role of the base category in the choice experiment. 
Table 1. Product attributes and level used in the choice experiment.

\begin{tabular}{|c|c|c|c|c|}
\hline Attribute & Level 1 (Base) & Level 2 & Level 3 & Level 4 \\
\hline Check-in/Check-out & $\begin{array}{l}\text { At the reception } \\
\text { (during visitor stay) }\end{array}$ & $\begin{array}{l}\text { Via touch screen app } \\
\text { (reception, during } \\
\text { visitor stay) }\end{array}$ & Via mobile app & Via eye scan technology \\
\hline Hotel Room Ambience & $\begin{array}{l}\text { Control through the } \\
\text { traditional way }\end{array}$ & Control through tablet or tv & $\begin{array}{l}\text { Control through } \\
\text { mobile app }\end{array}$ & Voice activation control \\
\hline Hotel's Energy Savings & $\begin{array}{l}\text { Light Emitting Diode } \\
\text { (LED) lighting } \\
\text { throughout the hotel }\end{array}$ & $\begin{array}{l}\text { Base }+ \text { all electrical } \\
\text { equipment is } \mathrm{A}++\end{array}$ & $\begin{array}{c}\text { Base }+ \text { smart windows } \\
\text { technology }\end{array}$ & $\begin{array}{l}\text { Base }+ \text { bioclimatic } \\
\text { architecture }\end{array}$ \\
\hline $\begin{array}{l}\text { Hotel's Environmental } \\
\text { Policy Certification } \\
\text { Standards }\end{array}$ & $\begin{array}{l}\text { Certified by a 3rd party } \\
\text { (e.g., International } \\
\text { Organization for } \\
\text { Standardization, ISO) }\end{array}$ & No policies in place & $\begin{array}{l}\text { Industry based } \\
\text { certification }\end{array}$ & $\begin{array}{l}\text { European Union (EU) } \\
\text { ecolabel }\end{array}$ \\
\hline $\begin{array}{c}\text { Hotel's Waste } \\
\text { Management Policy }\end{array}$ & $\begin{array}{l}\text { Policies to responsibly } \\
\text { manage waste } \\
\text { produced at the hotel }\end{array}$ & No policies in place & $\begin{array}{l}\text { Policies to reuse waste } \\
\text { produced at the hotel }\end{array}$ & $\begin{array}{l}\text { Policies to recycle waste } \\
\text { produced at the hotel }\end{array}$ \\
\hline Price & EUR 70 pp per night & EUR 74 pp per night & EUR 77 pp per night & EUR 81 pp per night \\
\hline
\end{tabular}

The "Check-in/Check-out" attribute refers to the way that hotel guests announce their arrival/departure. It is considered as one of the key hotel attributes that influence tourists' hotel selection and the experience during the holiday period, and thus their utility levels [32]. Additionally, following the commentary by $[23,33]$, the Check in/out product attribute could be utilized to evaluate consumers' approaches to service personalization before the actual consumption of the hospitality service (upon their arrival to the hotel). The base level here is check in/out at the reception as it is done currently. Level two could be still at the reception but this time through a touch screen system, whereby the hotel guest could complete some other features of his/her trip. Level three could be checking in/out through a mobile device before the actual arrival or departure at/from the hotel. In addition to that, checking in through a mobile device could also offer a number of options/possibilities for the guest. From selecting his/her own room, opting for the type of neighbors he/she would have next to the room, to various other services. The highest level, level four of this attribute is check in/out via eye scan technology, an advanced technology that represents a future but still hypothetical state of the current situation.

The "Room Control Ambience" attribute refers to some basic environmental, technological or operational setup of the hotel room such as room temperature, room lighting level, room cleaning order, room service calling/order, etc. The base level here is the traditional way that refers to traditional room control with the use of a separate device, the usage of the telephone for the communication with the reception/bar/restaurant, etc. Level two is the room control though applications that the guest can use with a tablet or TV device in the room. Level three presents room control though a mobile application that the guest can use from his mobile phone/device during his stay, while the fourth level is voice activation room control.

A basic energy/environmental attribute referred to many studies [34], is the "Hotel's Energy Savings" practices. The base level here is the lighting of the hotel with light emitted diode (LED) technology (it is common for the hotels to replace old lighting lamps with LED lamps). In level two, the hotel's electrical equipment could be considered as an A+++ energy-saving equipment. Level three is the high efficiency (and expensive) technology of smart windows. The bioclimatic architecture is the fourth level in the "Hotel's Energy Savings" attribute.

The "Hotel's Environmental Policy" indicates the general effort/philosophy of a hotel for best practices in the environmental/energy field. According to the literature in the field [35,36], the hospitality sector is being increasingly aware of its environmental externalities and thus, it is not uncommon of (especially) big hotels to implement environmental management practices nowadays. This attribute 
can include not only the existing policy and efforts (e.g., technology), but also the right communication of this effort to customers and other stakeholders, as well as the tendency of the hotel to be continuously improved in this field. The base level here could be the third-party certification of the hotel for its smart policy/procedures (e.g., the International Organization for Standardization ISO certification). In level two the situation could be where the hotel does not have any environmental policy, while in level three the hotel acquires industry-driven certifications. Level four is the European Union (EU) ecolabel certification which could be considered as the most important and difficult certification to acquire.

The "Hotel's Waste Management" attribute could involve many technologies or practices which are included in the general definition of smart hotel. The base level here could be technologies or practices that a hotel adopted for the reduction of production of waste. Level two describe the absence of waste management policy. Level three and four could be technologies or practices that a hotel adopted for reusing and recycling of waste, respectively.

The "Hotel's Water Management" attribute seems to be important attribute, since water considered as a scare resource and its protection evolves technologies that can be expensive for hotels. According to [37], water management is going to feature very prominently in tourism management in the future for a number of reasons.

- First, due to rising tourism demand, future needs to support the tourism industry would exert pressure on water usage and availability. Tourism is a heavy water user for concurrent tourism and hospitality activities (swimming pools, gardening at hotels, and other recreational activities), so any further rise in tourism activity, would certainly imply a parallel increase in water consumption. It is long known that consumers use more water when on holidays, as compared to their home/domestic water usage patterns [38].

- Second, based on the discussion in [38], the majority of tourism activity is taking place in water-poor countries (the Mediterranean countries are falling under this category). Considering that current projections indicate that Europe and the Mediterranean countries will receive the majority of tourism demand, it is no false to assume that these regions will also face more pressing water management issues. Interestingly, reference [39] have mentioned that Greece will eventually experience considerable negative social effects from rising tourism demand levels because intensified water requirements from the hospitality and tourism sector will create tensions with residents and local populations.

- Third, especially for Greece and the Mediterranean countries, the type of tourism activity (and visitors' behavioral patterns) is going to feature very significantly as far as water demand/consumption is concerned. This is because hotel guests tend to exhibit the so-called 'pleasure approach' when on holidays [37]. This implies that, when on holiday, typical tourists tend to consume more water (to shower and bath) compared to their everyday life. This tendency is confirmed in the case of Greece [39].

As a base level in this attribute could be an existing but ineffective effort of water management made by hotels. The second level refers to hotels that do not have any water protection technology or practice at all. On first reading, this decision might appear to be rather odd. What is meant here is that level 2 of this particular product attribute represents deterioration from the base level (i.e., the current state of the world). However, the literature does argue that the firm's ability to implement water management practices and initiatives is related to its size [40] and clientele [41]. For example, small hotel units may lack specialized personnel to implement water management practices, or even simpler, water management practices and initiatives may be too costly for them. In addition to that, the authors of [19] have argued that tour operators exhibiting oligopsonistic behavior towards hotels in Greece actively encourage owners and managers to abstain from such practices. In this case, setting up this kind of policy initiatives would leave a negative net effect for the hospitality firm and the local community in general. Therefore, from this perspective, it makes better sense not to engage in such practices and instead focus attention and resources elsewhere. This is a conclusion that is also being 
shared in the literature [42]. Thus, the decision not to engage on water management practices could be geared by survival instincts, as opposed to lack of awareness or foresight from hoteliers.

Levels three and four could be technologies or practices that a hotel adopted for the reduction of water usage and the reusing of water, respectively. In particular, the paper supports the classification proposed by [37], in that the third product level (water reduction) implies limited resources, limited (expert) knowledge and is best suited for small- and medium-sized hotels. For water reduction practices to be effective, hotels need to rely extensively on their personnel (i.e., close monitoring of possible leaks, day-to-day management and inspection). Thus, water reduction practices are better described as micro-management practices that require little innovation but considerable attention and inspection (or alternatively human resource management strategies). On the other hand, water reusing practices (level four) is technology intensive, but requires minimal knowledge on how to implement these practices (re-use of water) effectively. Therefore, whereas water reduction basically means the utilization of human resources to micro-manage the everyday operation of the hotel in as far as water is concerned, reusing water requires a change in the way hotels tend to operate (collect rainwater or building smaller pools).

\section{The Choice Experiment Survey}

A choice modeling survey was carried out in the broader area of Heraklion, Crete, Greece. The selection of Crete and Heraklion as the case study location could be explained on multiple grounds. First, Crete is the largest Greek island, and the second most popular tourist destination in Greece, following Athens. At the same time, the hospitality sector in Crete boasts the 2nd largest concentration of $5^{*}$ hotel units in Greece [43]. Crete also accounts for $20 \%$ of all tourism receipts in Greece [43], while it also accounts for $12 \%$ of all employees in the tourism sector in Greece (3rd highest) [43]. Meanwhile, the Heraklion prefecture dominates tourism activity in Crete (concentration of luxury hotel accommodation, tourism receipts, as well as tourism employment). The Heraklion international airport handles the overwhelming majority of tourist arrivals on the island and, for this reason, the city is considered to be the tourism gateway on the island. In addition, and equally important, a number of smart and green hotels have recently started operating in Heraklion (e.g., Olive Green Hotel). Thus, the concept of smart hospitality is not foreign to either the guests or the locals, minimizing in this way potential cultural conflicts [23]. According to [44], this 'embedded knowledge' is quite important for researchers and practitioners alike.

The choice experiment survey targeted visitors irrespective of whether they had attended a smart or green hotel in the past. Respondents to the questionnaire were asked about their general tourism preferences and their preferences while they were on holidays in Crete. In addition, the questionnaires inquired about respondents' personal characteristics. Five hundred self-administered questionnaires were distributed randomly in hotels in Heraklion and the Heraklion International Airport. Due to the airport's significance and the volume of tourists it accommodates, it made sense to utilize it as a potential location for the administration of the stated preferences discrete choice experiment survey.

According to [31], there is no agreement on the correct size of the sample in SPDCM experiments. Based on [45,46], samples between 150 and 300 respondents are deemed as optimal for SPDCM studies. In terms of the sampling procedure, the study adopted a choice-based sampling strategy to ensure randomness. According to [47], choice-based sampling approaches ensure that all choice alternatives in the study are selected once by the participants in the choice experiment. In addition to that, the study made sure to recruit participants proportionately to the general socio-demographic population of tourists visiting Crete during the summer months.

Each survey questionnaire contained three unique choice experiments (cards). Each choice experiment comprised of a pair wise choice set (identified through the seven product attributes and their levels) as well as a 'no-visit' option. Thus, each discrete choice experiment contained six choice alternatives $(2 * 3)$ and three 'no-visit' $(1 * 3)$ options. The block design routine in SAS was used to produce these unique pair-wise combinations so that each combination of choice alternatives 
was to be presented only once to each respondent. This procedure introduced randomness in the design. In total, the survey collected 4500 unique observations (500 survey questionnaires $* 3$ choice experiments $* 3$ options). Table 2 below, presents an example of a choice card that was used in order to elicit individual preferences for smart hotels in Crete.

Table 2. An Example of a Choice Card.

\begin{tabular}{|c|c|c|c|}
\hline \multicolumn{4}{|c|}{$\begin{array}{l}\text { Imagine that for your future holiday stay, you are offered the following two options. Which option (A or B) would you } \\
\text { choose? }\end{array}$} \\
\hline & Hotel A & Hotel B & \\
\hline Check in/out & Via mobile app & Via eye scan technology & \multirow{7}{*}{$\begin{array}{l}\text { Neither of the } \\
\text { two options }\end{array}$} \\
\hline Hotel Room Ambience & Control through tablet or television & Control through mobile app & \\
\hline $\begin{array}{l}\text { Hotel's Energy-Saving } \\
\text { Policies }\end{array}$ & $\begin{array}{c}\text { LED lighting }+ \\
\text { bioclimatic architecture }\end{array}$ & $\begin{array}{l}\text { LED lighting + all electrical } \\
\text { equipment is } \mathrm{A}++\end{array}$ & \\
\hline $\begin{array}{l}\text { Hotel's Environmental } \\
\text { Certification Standards }\end{array}$ & Industry-based certification & No policies in place & \\
\hline $\begin{array}{l}\text { Hotel's Waste } \\
\text { Management Policy }\end{array}$ & $\begin{array}{l}\text { Policies to recycle waste produced } \\
\text { at the hotel }\end{array}$ & $\begin{array}{c}\text { Policies to reuse waste produced } \\
\text { at the hotel }\end{array}$ & \\
\hline $\begin{array}{l}\text { Hotel's Wastewater } \\
\text { Policy }\end{array}$ & $\begin{array}{l}\text { Policies to reuse water waste at } \\
\text { the hotel }\end{array}$ & $\begin{array}{c}\text { Policies to reduce water waste at } \\
\text { the hotel }\end{array}$ & \\
\hline \multirow[t]{2}{*}{ Price } & EUR 70 pp per night & EUR 77 pp per night & \\
\hline & Option $\mathbf{A}_{\square}$ & Option $\mathbf{B}_{\square}$ & Option $\mathrm{C}_{\emptyset}$ \\
\hline
\end{tabular}

\section{Results}

\subsection{Demographics and General Characteristics of the Sample}

In addition to the responses to the choice experiment, other data were collected using the questionnaire, including respondents' attitudinal and socio-demographic characteristics. The sample's demographic characteristics are presented in Table 3 below.

Table 3. Socio-Demographic Profile of the Sample (percentages).

\begin{tabular}{|c|c|c|c|}
\hline Age & & Travelling Party Composition & \\
\hline Up to 25 years of age & 21.4 & Travel alone & 6.4 \\
\hline 26 to 45 years of age & 40.2 & With partner (only) & 57.6 \\
\hline \multirow{2}{*}{$\begin{array}{l}46 \text { to } 65 \text { years of age. } \\
65+\text { years of age }\end{array}$} & 29.8 & With family and kids & 19.2 \\
\hline & 8.7 & With group of adults & 17.4 \\
\hline Marital Status & \multicolumn{3}{|c|}{ Educational Background } \\
\hline Single & 24.8 & Still in education & 11.2 \\
\hline Married & 46.4 & Completed basic level of education & 13.6 \\
\hline In a civil partnership & 17.8 & Vocational training & 7.2 \\
\hline Other & 11.0 & Bachelor's degree (BA/BSc) & 33.2 \\
\hline \multicolumn{2}{|l|}{ Gender } & Post-graduate degree (MA/MSc) & 34.8 \\
\hline Male & 48.2 & \multicolumn{2}{|l|}{ Country of Origin } \\
\hline Female & 51.8 & UK & 40.2 \\
\hline \multicolumn{2}{|l|}{ Working Status } & Germany & 24.8 \\
\hline $\begin{array}{l}\text { In full-time } \\
\text { employment }\end{array}$ & 64.2 & France & 7.8 \\
\hline $\begin{array}{l}\text { In part-time } \\
\text { employment }\end{array}$ & 10.8 & Netherlands & 5.6 \\
\hline Student/Unemployed & 13.2 & Other & 21.4 \\
\hline \multirow[t]{5}{*}{ Other } & 12.0 & Income Levels & \\
\hline & & Up to 20,000 & 27.0 \\
\hline & & 20,001 to 40,000 & 26.6 \\
\hline & & 40,000 to 60,000 & 23.4 \\
\hline & & 60,001 and over & 23.0 \\
\hline
\end{tabular}




\subsection{Results from Multinomial Logit Model (MNL)}

All discrete choice modeling specifications were estimated using the STATA 7 statistical package. Table 4 reports individual preferences for future or hypothetical smart hotel configurations in Crete under a homogeneous preference specification model.

Table 4. Multinomial Logit Model (MNL) Coefficients from Choice Experiment.

\begin{tabular}{|c|c|}
\hline Product Attributes & Beta $(\beta)$ Coefficients \\
\hline $\begin{array}{c}\text { Constant } \ldots \ldots \ldots \ldots \ldots \ldots \ldots \ldots \ldots \ldots \ldots \\
{ }_{1} \ldots \ldots \ldots \ldots \ldots \ldots \ldots \ldots \ldots \ldots \ldots\end{array}$ & $-0.157(0.006)^{* * *}$ \\
\hline \multicolumn{2}{|l|}{ Check-in/Check-out } \\
\hline $\begin{array}{l}\text { At the reception } \ldots \ldots \ldots \ldots \ldots \ldots \ldots \ldots \ldots \\
\ldots \ldots \ldots \ldots \ldots \ldots \ldots \ldots \ldots \ldots \ldots\end{array}$ & (Base) \\
\hline $\begin{array}{l}\text { Via touch screen } \text { app } \ldots \ldots \ldots \ldots \ldots \ldots \ldots \ldots \\
\ldots \ldots \ldots \ldots \ldots \ldots \ldots \ldots \ldots \ldots\end{array}$ & $-0.251(0.0147)^{* *}$ \\
\hline $\begin{array}{l}\text { Via mobile app } \ldots \ldots \ldots \ldots \ldots \ldots \ldots \ldots \ldots \\
\ldots \ldots \ldots \ldots \ldots \ldots \ldots \ldots \ldots \ldots \ldots\end{array}$ & $-0.335(0.0014)^{* *}$ \\
\hline $\begin{array}{l}\text { Via eye scan technology } \ldots \ldots \ldots \ldots \ldots \ldots \ldots \\
\ldots \ldots \ldots \ldots \ldots \ldots \ldots \ldots\end{array}$ & $-0.717(0.000)^{* * *}$ \\
\hline \multicolumn{2}{|l|}{ Hotel room ambience } \\
\hline $\begin{array}{l}\text { Control through traditional way } \ldots \ldots \ldots \ldots \\
\ldots \ldots \ldots \ldots \ldots \ldots \ldots \ldots \ldots \ldots \ldots\end{array}$ & (Base) \\
\hline $\begin{array}{l}\text { Control through tablet or } \operatorname{tv} \ldots \ldots \ldots \ldots \ldots \ldots \\
\ldots \ldots \ldots \ldots \ldots \ldots \ldots \ldots \ldots \ldots\end{array}$ & $0.221(0.032) * *$ \\
\hline $\begin{array}{l}\text { Control through mobile app } \ldots \ldots \ldots \ldots \ldots \\
\ldots \ldots \ldots \ldots \ldots \ldots \ldots \ldots \ldots \ldots\end{array}$ & $0.004(0.967)$ \\
\hline $\begin{array}{l}\text { Voice activation control } \ldots \ldots \ldots \ldots \ldots \ldots \ldots \\
\ldots \ldots \ldots \ldots \ldots \ldots \ldots \ldots \ldots\end{array}$ & $-0.088(0.399)$ \\
\hline \multicolumn{2}{|l|}{ Hotel's Energy Savings } \\
\hline $\begin{array}{l}\text { LED lighting throughout the hotel } \ldots \ldots \ldots \ldots \\
\ldots \ldots \ldots \ldots \ldots \ldots \ldots \ldots \ldots\end{array}$ & (Base) \\
\hline $\begin{array}{l}\text { Base }+ \text { all electrical equipment is } \mathrm{A}++\ldots \ldots \ldots \\
\ldots \ldots \ldots \ldots \ldots \ldots \ldots \ldots\end{array}$ & $0.263(0.012)^{* *}$ \\
\hline $\begin{array}{l}\text { Base }+ \text { smart windows technology } \ldots \ldots \ldots \ldots \\
\ldots \ldots \ldots \ldots \ldots \ldots \ldots \ldots \ldots\end{array}$ & $0.366(0.000)^{* * *}$ \\
\hline $\begin{array}{l}\text { Base }+ \text { Bioclimatic architecture } \ldots \\
\ldots \ldots \ldots \ldots \ldots \ldots \ldots \ldots\end{array}$ & $0.458(0.000)^{* * *}$ \\
\hline \multicolumn{2}{|l|}{$\begin{array}{c}\text { Hotel's Environmental Policy Certification } \\
\text { standards }\end{array}$} \\
\hline $\begin{array}{l}\text { Certified by a third Party (e.g., ISO) } \ldots \ldots \ldots \\
\ldots \ldots \ldots \ldots \ldots \ldots \ldots \ldots \ldots \ldots\end{array}$ & (Base) \\
\hline $\begin{array}{l}\text { No policies in place } \ldots \ldots \ldots \ldots \ldots \ldots \ldots \ldots \ldots \\
\ldots \ldots \ldots \ldots \ldots \ldots \ldots \ldots \ldots \ldots\end{array}$ & $-0.445(0.000)^{* * *}$ \\
\hline $\begin{array}{l}\text { Industry based certification } \ldots \ldots \ldots \ldots \ldots \ldots \\
\ldots \ldots \ldots \ldots \ldots \ldots \ldots \ldots \ldots \ldots\end{array}$ & $0.109(0.295)$ \\
\hline $\begin{array}{c}\text { EU Ecolabel } \ldots \ldots \ldots \ldots \ldots \ldots \ldots \ldots \ldots \ldots \ldots \ldots \ldots \ldots \ldots \ldots \ldots \ldots \ldots \ldots \ldots \ldots \ldots \ldots \\
\ldots \ldots \ldots \ldots \ldots \ldots \\
\text { Hotel's Waste Management Policy }\end{array}$ & $-0.076(0.462)$ \\
\hline $\begin{array}{l}\text { Policies to responsibly manage waste produced } \\
\text { by hotel................. }\end{array}$ & (Base) \\
\hline $\begin{array}{l}\text { No policies in place } \ldots \ldots \ldots \ldots \ldots \ldots \ldots \ldots \\
\ldots \ldots \ldots \ldots \ldots \ldots \ldots \ldots \ldots \ldots \ldots\end{array}$ & $-0.702(0.000)^{* * *}$ \\
\hline $\begin{array}{l}\text { Policies to Reuse waste produced by hotel } \ldots \\
\ldots \ldots \ldots \ldots \ldots \ldots \ldots \ldots \ldots\end{array}$ & $-0.022(0.821)$ \\
\hline $\begin{array}{l}\text { Policies to Recycle waste produced by hotel } \ldots \\
\ldots \ldots \ldots \ldots \ldots \ldots \ldots \ldots\end{array}$ & $0.154(0.098)^{*}$ \\
\hline
\end{tabular}


Table 4. Cont.

\begin{tabular}{|c|c|}
\hline Product Attributes & Beta $(\beta)$ Coefficients \\
\hline Hotel's Water Management & \\
\hline $\begin{array}{l}\text { No effective water management policy } \ldots \ldots \\
\ldots \ldots \ldots \ldots \ldots \ldots \ldots \ldots \ldots\end{array}$ & (Base) \\
\hline $\begin{array}{l}\text { No policies in place } \ldots \ldots \ldots \ldots \ldots \ldots \ldots \ldots \\
\ldots \ldots \ldots \ldots \ldots \ldots \ldots \ldots \ldots \ldots \ldots\end{array}$ & $0.188(0.078) *$ \\
\hline $\begin{array}{l}\text { Policies to Reduce water waste at hotel } \ldots \ldots \\
\ldots \ldots \ldots \ldots \ldots \ldots \ldots \ldots\end{array}$ & $0.761(0.078) *$ \\
\hline $\begin{array}{l}\text { Policies to Reuse water waste at hotel } \ldots \ldots \ldots \\
\ldots \ldots \ldots \ldots \ldots \ldots \ldots \ldots\end{array}$ & $0.667(0.000)^{* * *}$ \\
\hline Price & $-0.258(0.000)^{* * *}$ \\
\hline $\begin{array}{l}\text { Observations }(\mathrm{N}) \ldots \ldots \ldots \ldots \ldots \ldots \ldots \ldots \ldots \\
\ldots \ldots \ldots \ldots \ldots \ldots \\
\ldots \ldots \ldots \ldots\end{array}$ & 4500 \\
\hline $\mathrm{LL} \ldots \ldots \ldots \ldots \ldots \ldots \ldots \ldots \ldots \ldots$ & -2864.76 \\
\hline $\begin{array}{l}\begin{array}{l} \\
\text { McFadden Pseudo R-squared } \ldots \ldots \ldots \ldots \ldots \\
\ldots \ldots \ldots \ldots \ldots \ldots \ldots \ldots\end{array} \ldots \ldots \ldots \\
\ldots \ldots \ldots\end{array}$ & 12.01 \\
\hline
\end{tabular}

Starting from the most important (and the simplest), the beta coefficient for the price attribute (price of a standard room on a smart hotel), that is the price attribute, is statistically significant and negative. This aligns with standard economic theory and basically confirms the validity of the choice experiment. The constant coefficient (denoting the current state of the world) is also negative and statistically significant, indicating that tourists are very much appreciative of the alternative policy and managerial provisions we described in the choice experiments. This finding also aligns with the current discussion in the literature, in the sense that it provides further evidence regarding tourists' support towards similar initiatives $[4,26,48,49]$.

Indicatively, all 'Check in/out' level configurations or product attributes are negative and statistically significant. This rather interestingly implies that visitors tend to prefer the current state of the world (i.e., respondents seem to prefer things as they stand right now as far as their check-in and check-out options are concerned). In other words, it appears that respondents expressed negative feelings about checking-in/-out options that did not involve direct human interaction (that is via touch screens, mobile apps or eye scan technology). According to [23], this is positive news from a societal perspective. In the current context, smart developments would not seem to affect the labor-intensive nature of the hospitality sector. From a policy perspective, the results indicate that tourists do not seem to appreciate recent efforts to involve them in the service delivery process (touch screen), or distancing them from the front office service personnel (mobile apps and eye scan technology). Additionally, these results could also be interpreted as if respondents are apparently rather negative towards any efforts to further customize and differentiate the service provision at hotels.

Again, this piece of evidence is rather puzzling at first since it runs counter to established wisdom in the literature $[33,50,51]$. One could argue instead that there appears to be a continuum of customization or how far managers and hoteliers can go with respect to service differentiation. Overall, these results point to the conclusion that, despite the overwhelming acceptance that information communication technologies have received in the literature, visitors are still fond of the human interaction and involvement. In the current setting of a mass tourist destination, this finding becomes even more significant in the sense that it emphasizes the need to restrict the industry's exposure to technology, and instead invest on human resources.

In the "Hotel Room Ambience" attribute, only the configuration relating to room control through tablet or TV is positive and statistically significant. This is also a case where one could argue that guests do not seem to appreciate further service differentiation and customization. One could also argue that this pattern of preferences is due to visitors' low or limited technological awareness and 
understanding [11]. From this perspective, the current empirical findings certainly seem to provide support for the choice inertia hypothesis in the literature worldwide [52], as well as in a Greek context [22,53]. Essentially, visitors in Crete are not willing to change their preferences towards other smart system configurations within a hospitality setting, simply because they do not want to deviate from their daily normal routine [18]. An alternative explanation for this apparent unwilling stance from respondents could be due to an element of unfamiliarity or lack of user friendliness (in the case of voice activation control systems) [44]. Certainly, being a mass tourist destination could imply that a large proportion of visitors to Crete may find these systems useful, but rather difficult to cope with. Therefore, either due to low levels of technological awareness, or choice inertia, visitors to Crete do not seem to express positive preferences towards more complex hotel ambience systems.

All level configurations in "Hotel's Energy Savings" attribute are positive and statistically significant. Tourists potentially prefer for their stay hotels that implement energy-saving practices, ranging from the more familiar ones (e.g., electrical equipment with A++ energy class) to the most advanced, such as smart windows and bioclimatic design. In this respect, the present empirical findings seem to confirm [6], as well as point [54] towards the significance of energy-saving technologies in a hospitality context. It seems that energy-saving policy initiatives is of particular importance to tourists visiting Crete. In particular, the current results run parallel to [21] empirical findings. In particular, they argue that environmental conscious tourists in Crete are willing to pay a higher premium in their accommodation for more energy efficient holiday dwellings. The current set of empirical findings is quite promising for one additional reason. Considering the fact that Crete is a mass tourist destination suffering every year from energy shortages during the summer high season [22,55], the currently reported empirical findings suggest that investing in energy-saving technologies is a policy initiative that visitors are most likely to approve and support.

In accordance to the points raised in earlier parts of the paper, the results from the certification policy attribute reveal that tourists seem to consider favorably the base category (current state of the world for many hotels), the existence of environmental standards certified by a 'third party (e.g., ISO)'. The beta coefficient for the 'no policies in place' policy configuration, which indicate the absence of any environmental policy (certified or not), is significantly negative, as compared to the status quo (current state of the world). This finding implies tourists' willingness to support some kind of hotel environmental policy. Essentially, these results indicate that tourists are keen for some sort of independently regulated environmental certification scheme in the hospitality sector. From this perspective, the empirical findings align with the information provided by [56,57]. It is also interesting to note that respondents seem to be in favor of initiatives that do not include any value judgments (certificates), as opposed to policy schemes that entail some sort of value judgment from the issuing body (eco-labels) [58].

Concerning the "Hotel's Waste Management Policy" attribute, the empirical results provide a number of interesting pieces of information. First, the absence of any waste management policy is significantly negative. Respondents indicated strong and negative preferences towards the absence of waste management policies in hotels, as compared to the base (some policy to responsibly manage waste produced by the hotel). Thus, tourists are clearly in favor of some smart policy initiative that involves managing waste as a by-product of the hotel's operations. Second, the empirical findings indicate that recycling policies are considered favorably by tourists in Crete. Following the rationale by [10], tourists may perceive waste reuse policies more economical or rather less inconvenient for them. Interestingly, these results confirm earlier empirical findings in a hospitality context $[59,60]$. Thus, visitors are prepared to support any smart policy initiative that contributes to the environment and at the same time, adds to their experience (recycling), or does not affect their convenience levels [44].

Tourists' desire for proper water management procedures from the hospitality industry is also highlighted in the results. Again, there is a number of interesting points emerging from the discussion of the water management policy attribute in smart hotels. Initially, respondents seem to favor the adoption of no policy initiatives, as opposed to policy initiatives that do not generate any significant 
results. This empirical result is pointing out is that when it comes to smart and green solutions, everything should come into perspective. Water management, as opposed to waste management that is a more affordable practice, is a rather costly business for small hotels. Indeed, the literature in the field [40] argues that the efficiency of water management policies and practices depends on the relative size of the hotel. Small- and medium-sized hotels cannot afford to effectively and efficiently perform water management policy initiatives [19]. This point seems to be relevant on guests' evaluations. What they are saying is that if a hotel is not of the right scale of operations (too small in other words) it should better allocate its (scarce) resources into something else (that is going to be more efficient, or make a greater impact).

Second, policies geared towards reducing water wastage, as well as water reuse are considered favorably by respondents, as compared to policies that do not manage to efficiently manage water usage in hotels. These results confirm [38] as far as Greece and Crete are concerned. In particular, reference [61] argue that water management is of particular importance to Mediterranean countries twofold. On the one hand, the majority of Mediterranean countries (Greece and Crete included) are water-poor countries. Thus, any effort to conserve water is considered as very important [62]. On the other hand, the majority of tourism activity in mass tourist destinations, such as Crete, depends upon water [10]. Hence, tourists' preferences for alternative water management policy initiatives in Cretan hotels could be translated through the social identity theory [52]. On a second note, these results indicate that respondents seem to appreciate both 'easy' to perform policy initiatives (reduction of water wastage that can even be achieved with better training of the hotel's human resources) as well as more technically challenging solutions (water reuse requires more technically accomplished personnel to manage this).

\subsection{Willingness to Pay (WTP) Estimates}

Diving each beta coefficient with $X 7$ (price) provides the marginal willingness to pay estimates, that is how much each respondent would be willing to pay (in order) to get each particular smart and green policy initiative. This information is presented in Table 5 below.

Table 5 translates individual preferences into willingness to pay (WTP) estimates. Therefore, it assigns a EUR sign into respondents' preferences patterns. The interpretation of choice patterns into monetary estimates lies at the heart of the evaluation exercise. The discussion will only consider statistically significant results. According to the results presented in Table 5, it appears that respondents expressed rather strong negative preferences for the check in-out product attribute. More specifically, respondents indicated that they would be willing to pay almost EUR 1 less as a result of the introduction of a touch screen application at the reception to expedite check-in and -out procedures. Similarly, respondents would be willing to pay EUR 1.3 and almost EUR 2.8 less for the introduction of mobile applications and eye scan technology respectively, to facilitate the check in and checkout activities. 
Table 5. Marginal Willingness to Pay Estimates (in EUR).

\begin{tabular}{|c|c|}
\hline Product Attributes & MWTP Estimates \\
\hline \multicolumn{2}{|l|}{ Check-in/Check-out } \\
\hline At the $\operatorname{reception} \ldots \ldots \ldots \ldots \ldots \ldots \ldots \ldots \ldots \ldots \ldots \ldots \ldots \ldots \ldots \ldots \ldots$ & (Base) \\
\hline 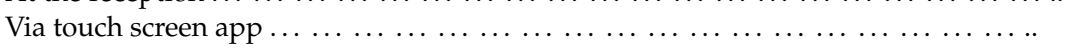 & -0.97 \\
\hline Via mobile $a p p(\ldots \ldots \ldots \ldots \ldots \ldots \ldots \ldots \ldots \ldots \ldots \ldots \ldots \ldots \ldots \ldots$ & -1.32 \\
\hline 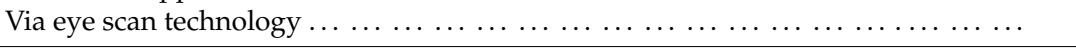 & -2.78 \\
\hline \multicolumn{2}{|l|}{ Hotel room ambience } \\
\hline Control through traditional way $\ldots \ldots \ldots \ldots \ldots \ldots \ldots \ldots \ldots \ldots$ & (Base) \\
\hline Control through tablet or $t v \ldots \ldots \ldots \ldots \ldots \ldots \ldots \ldots \ldots \ldots \ldots \ldots \ldots$ & 0.87 \\
\hline Control through mobile app $\ldots \ldots \ldots \ldots \ldots \ldots \ldots \ldots \ldots \ldots \ldots \ldots$ & 0.015 \\
\hline 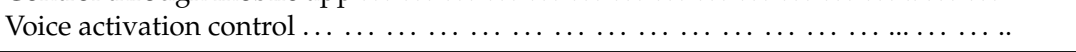 & -0.34 \\
\hline \multicolumn{2}{|l|}{ Hotel's Energy Savings } \\
\hline LED lighting throughout the hotel $\ldots \ldots \ldots \ldots \ldots \ldots \ldots$ & (Base) \\
\hline Base + all electrical equipment is $\mathrm{A}++\ldots \ldots \ldots \ldots \ldots \ldots \ldots \ldots \ldots$ & 1.02 \\
\hline Base + smart windows technology $\ldots \ldots \ldots \ldots \ldots \ldots \ldots \ldots \ldots \ldots \ldots$ & 1.42 \\
\hline Base + Bioclimatic architecture $\ldots \ldots \ldots \ldots \ldots \ldots \ldots \ldots \ldots \ldots \ldots$ & 1.77 \\
\hline \multicolumn{2}{|l|}{ Hotel's Environmental Policy Certification standards } \\
\hline Certified by a third Party (e.g., ISO) . & (Base) \\
\hline No policies in place $\ldots \ldots \ldots \ldots \ldots \ldots \ldots \ldots \ldots \ldots \ldots \ldots \ldots \ldots \ldots$ & -1.72 \\
\hline Industry based certification $\ldots \ldots \ldots \ldots \ldots \ldots \ldots \ldots \ldots \ldots \ldots \ldots \ldots \ldots$ & 0.42 \\
\hline EU Eco-label ... . . . . . . . . . . . . . . . . . . . . . . . . . . . . . . . . . & -0.29 \\
\hline \multicolumn{2}{|l|}{ Hotel's Waste Management Policy } \\
\hline Policies to responsibly manage waste produced by hotel ......... & (Base) \\
\hline$\ldots \ldots \ldots \ldots \ldots \ldots \ldots \ldots \ldots$ & -2.73 \\
\hline Policies to Reuse waste produced by hotel ......... & -0.085 \\
\hline Policies to Recycle waste produced by hotel ... . . . . . . . . . . . . & 0.57 \\
\hline \multicolumn{2}{|l|}{ Hotel's Water Management } \\
\hline No effective water management policy $\ldots \ldots \ldots \ldots \ldots \ldots \ldots \ldots \ldots$ & (Base) \\
\hline 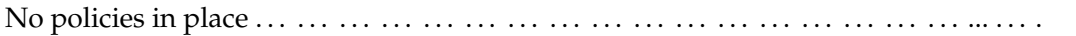 & 0.73 \\
\hline Policies to Reduce water waste at hotel $\ldots \ldots \ldots \ldots \ldots \ldots \ldots \ldots \ldots \ldots$ & 2.94 \\
\hline Policies to Reuse water waste at hotel $\ldots \ldots \ldots \ldots \ldots \ldots \ldots \ldots \ldots$ & 2.58 \\
\hline
\end{tabular}

For the "Hotel Room Ambience" attribute, respondents seem ready to pay almost EUR 0.9 more if the hotel gives them the ability to control their rooms through a tablet or a TV device. Maybe tourists consider that these mature IT technologies can offer them a sufficient comfort level for room controlling, which is positively evaluated for the assessment of their room.

Table 5 above also shows that respondents have strong positive preferences for all configurations of the "Hotel's Energy Savings" product attribute. Their willingness to pay for hotels using appliances with A++ energy class is greater and can be estimated to EUR 1.0 more in room rate. The results for the other two upper levels of the attribute are equally interesting. Respondents express that they are willing to pay EUR 1.4 and EUR 1.8 more for hotels adopting smart windows technology and bioclimatic architecture, respectively.

The analysis for "Hotel's certified environmental policy" attribute reveals that tourists are ready to pay EUR 1.72 less for hospitality units without environmental policies. This reduction in room rate clearly shows respondents' environmental concerns and how these concerns influence their consumption behavior patterns in the hospitality sector.

Similarly, the results regarding respondents' willingness to pay for the "Hotel's waste management" product attribute capture their strong environmental concerns about waste treatment in the hospitality sector. More specifically, respondents indicated that they would be willing to pay almost EUR 2.7 less as a result of the absence of any waste management policy by the hotels. One the other hand, respondents appear ready to pay almost EUR 0.6 more in room rates for hotels implementing waste recycling schemes. 
Finally, their willingness to pay more for a hotel room is boosted in case of hotels adopting water management technologies/policies. Results estimate that respondents are willing to pay almost EUR 3 and EUR 2.6, respectively, more for hotels applying policies that reduce and reuse water wasted at the hotel, as compared to the base (current state of the world). In other words, the less technologically advanced solution (that is for example training human resources to respond quicker into a reported water leakage) would benefit managers and practitioners more, as compared to a technologically advanced policy initiative. Thus, in this respect policy makers, managers and practitioners alike should realize that it does not always pay to opt for the more technologically savvy and advanced solution. Sometimes, it pays more to act and behave smart (i.e., putting the existing scarce human resources into better usage). Additionally, these empirical results tend to confirm the argument circulating in the literature regarding the significance of water management policies across water-poor countries $[10,62]$.

\section{Conclusions}

The current paper utilized a stated preferences discrete choice modeling approach to elicit individual (tourists') preferences for smart hotels in Crete. In particular, it described alternative future smart hotels provisions based on seven attributes. Each one of these seven attributes included four alternative levels, or configurations. The selection of this experimental method to elicit individual preferences for smart hotels in considered appropriate to the study aim. Stated preference discrete choice modeling facilitates the collection of evidence regarding consumers' opinions and behavioral patterns concerning future developments in the hospitality sector. Additionally, the paper translated individual preferences patterns in monetary terms (in EUR), through marginal willingness to pay estimates. Primary data were collected through survey questionnaires. Five hundred stated preference discrete choice modeling survey questionnaires were collected in total. The findings presented in the earlier parts of the paper have reached to a number of useful conclusions.

First, the empirical results denote that tourists to Crete are in general positive about smart policy initiatives in the hospitality sector in Greece. Second, it appears that tourist preferences for future or hypothetical smart hotel options are strongly dependent upon spatial as well as temporal and personal circumstances. This point seems to agree with the literature in the field. In essence, tourists' preferences for smart hotels seem to be affected by the geographical location of Crete. Being an island located in a water-poor region with fairly significant energy and water needs seems to play a significant role on visitors' preferences. This point, aligned with the fact that Crete represents an archetypal mass tourist destination (mature destination with high seasonality patterns), could allow for a greater generalization of the empirical findings to similar geographical settings.

Third, respondents rather interestingly seem to be dismissive of technological innovations that minimize human interaction (during the check in-out process). Tourists in Crete seem to value quite significantly human interaction in the service delivery process and are not keen to automate the process. Contrary to what the majority of the literature is proposing, tourists in Crete are keen to maintain human interaction in the hospitality sector. This empirical finding could be utilized twofold. On the one hand, it provides evidence to managers, policy makers and practitioners regarding the direction of future investments in the hospitality sector. Rather than focusing on greater automation in the delivery process, decision makers should be capitalizing on human resources and how best to train them to facilitate guests' interactions with other smart and green systems within a hotel. On the other hand, the results imply that decision makers do not need to invest significant amounts of money in order to cater for the divergent tourists' needs and preferences. Overall, and from a policy perspective, this set of empirical findings would tend to suggest that decision makers, hospitality owners, as well as practitioners should focus more on new and flexible workforce models in the (mass) hospitality sector. A more flexible, highly skilled and mobile workforce may be better equipped at dealing the highly unpredictable, dynamic and ever-changing tourism demand at mass tourist destinations.

Fourth, and related to the above, respondents' preferences and choice patterns for smart hotels in Crete seem to exert strong choice inertia features. In other words, respondents in this specific 
hospitality context seem to consider hotels as a 'home away from home'. Thus, their preferences and choice patterns are largely shaped by the set of their technological capabilities, daily routines as well as knowledge levels. At the same time, their choices seem to be influenced by the set of their own moral beliefs, priorities and social agenda. This is also an interesting finding because it dismisses the argument that modern consumers are wholeheartedly in support of smart solutions and constant technological change. The empirical findings instead assign greater significance on to information levels, users' familiarity and friendliness levels in order for this new technological disruption to catch up in mass tourist destinations. From a policy perspective, these empirical findings could be taken to imply that more effort and investment would be required to inform and educate actual and latent visitors, as opposed to actually acquiring these smart technologies.

What the abovementioned results have indicated is that hoteliers, managers and practitioners have to be aware of consumer preference patterns in order to best serve and offer high consumer experience. The current case study indicated that what matters the most is to offer smart solutions and technological innovations that consumers feel comfortable about. There is no need to financially commit to the latest technological innovation, or solution, without first enquiring what consumers are willing to support and comfortable to use. The key is to identify the configurations and service provisions that visitors seem to prefer and associate with.

Author Contributions: The research was designed and completed by all three authors. A.A. was responsible for the estimations, writing the manuscript, and dataset management (clearing, managing the data entry process). S.J. was responsible for the experimental design of the stated preferences discrete choice experiment and for conducting initial pilot tests. Finally, M.K. was responsible for the survey questionnaire, writing up the results, and the literature review section. All authors have read and agreed to the published version of the manuscript.

Funding: This research was funded by the Special Account of the Research Unit of Technological Educational Institute (TEI) of Crete Research Programme.

Conflicts of Interest: The authors declare no conflict of interest.

\section{References}

1. Ip, C.; Leung, R.; Law, R. Progress and Development of Information and Communication Technologies in Hospitality. Int. J. Contemp. Hosp. Manag. 2011, 23, 533-551. [CrossRef]

2. Gretzel, U.; Sigala, M.; Xiang, Z.; Koo, C. Smart Tourism: Foundations and Developments. Electron. Mark. 2015, 25, 179-188. [CrossRef]

3. Almeida, S.A. Smart Hospitality-Emerging Trends at the Front Office. Int. J. Res. Advent Technol. 2016, 4, 40-43.

4. Kontogianni, A.; Alepis, E. Smart Tourism: State of the Art and literature Review for the Last Six years. Array 2020, 6, 1-12. [CrossRef]

5. Ye, B.; Ye, H.; Law, R. Systematic Review of Smart Tourism Research. Sustainability 2020, 12, 3401. [CrossRef]

6. Kim, J.Y.; Sunyoung, H.; Joun, Y. Green Practices of the Hotel Industry: Analysis through the Windows of Smart Tourism Systems. Int. J. Inf. Manag. 2016, 36, 1340-1349. [CrossRef]

7. Porter, M.; Heppelmann, J. How Smart Connected Products Are Transforming Competition. Harv. Bus. Rev. 2014, 8, 1-23.

8. Shen, S.; Sotiriadis, M.; Zhou, Q. Could Smart Tourists Be Sustainable and Responsible as Well? The Contribution of Social Networking Sites to Improving Their Sustainable and Responsible Behavior. Sustainability 2020, 12, 1470. [CrossRef]

9. Law, R.; Leung, D.; Au, N.; Lee, H. Progress and Development of Information Technology in the Hospitality Industry: Evidence from Cornell Hospitality Quarterly. Cornell Hosp. Q. 2013, 54, 10-24. [CrossRef]

10. Kim, S.H.; Lee, K.; Fairhurst, A. The Review of 'Green' Research in Hospitality, 2000-2014: Current Trends and Future Research Directions. Int. J. Contemp. Hosp. Manag. 2017, 29, 226-247. [CrossRef]

11. Teng, C.C.; Cheng, A.; Lu, C.; Huang, T.T. Drivers of Consumers' Behavioral Intention towards Green Hotels. Int. J. Contemp. Hosp. Manag. 2018, 30, 1134-1151. [CrossRef]

12. Piccoli, G. Information Technology in Hotel Management A Framework for Evaluating the Sustainability of IT-Dependent Competitive Advantage. Cornell Hosp. Q. 2008, 49, 282-296. [CrossRef] 
13. Lockyer, T. The perceived importance of price as one hotel selection dimension. Tour. Manag. 2005, 26, 529-537. [CrossRef]

14. Li, G.; Law, R.; Vu, H.Q.; Rong, J. Discovering the Hotel Selection Preferences of Hong Kong Inbound Travelers Using the Choquet Integral. Tour. Manag. 2013, 36, 321-330. [CrossRef]

15. Masiero, L.; Heo, C.Y.; Pan, B. Determining guests' willingness to pay for hotel room attributes with a discrete choice model. Int. J. Hosp. Manag. 2015, 49, 117-124. [CrossRef]

16. Collins, M.; Parsa, H.G. Pricing strategies to maximize revenues in the lodging industry. Int. J. Hosp. Manag. 2006, 25, 91-107. [CrossRef]

17. Manaktola, K.; Jauhari, V. Exploring consumer attitude and behavior towards green practices in the lodging industry in India. Int. J. Contemp. Hosp. Manag. 2007, 19, 364-377. [CrossRef]

18. Baker, M.; Davis, E.; Weaver, P. Eco-Friendly Attitudes, Barriers to Participation and Differences in Behaviour at Greek Hotels. Cornell Hosp. Q. 2014, 55, 89-99. [CrossRef]

19. Law, R.; Buhalis, D.; Cobanoglu, C. Progress on Information and Communication Technologies in Hospitality and Tourism. Int. J. Contemp. Hosp. Manag. 2014, 26, 727-750. [CrossRef]

20. Bastakis, C.; Buhalis, D.; Butler, R. The Perception of Small and Medium Sized Tourism Accommodation Providers on the Impacts of the Tour Operators' Power in Eastern Mediterranean. Tour. Manag. 2004, 25, 151-170. [CrossRef]

21. Kostakis, I.; Sardianou, E. Which Factors Affect the Willingness of Tourists to Pay for Renewable Energy? Renew. Energy 2012, 38, 169-172. [CrossRef]

22. Parpairi, K. Sustainability and Energy Use in Small Scale Greek Hotels: Energy Saving Strategies and Environmental Policies. Procedia Environ. Sci. 2017, 38, 169-177. [CrossRef]

23. Buhalis, D.; Harwood, T.; Viglia, G.; Beldona, S.; Hofacker, C. Technological Disruptions in Services: Lessons from Tourism and Hospitality. J. Serv. Manag. 2019, 30, 484-506. [CrossRef]

24. Mehraliyev, F.; Chan, I.; Choi, Y.; Koseoglou, M.; Law, R. A State of-the-Art Review of Smart Tourism Research. J. Travel Tour. Mark. 2020, 37, 78-91. [CrossRef]

25. Wang, X.; Li, X.; Zhen, F.; Zhang, J. How Smart is Your Tourist attraction? Measuring Tourist Preferences of Smart Tourism Attractions via a FCEM-AHP and IPA Approach. Tour. Manag. 2016, 54, 309-320. [CrossRef]

26. Neuhofer, B.; Buhalis, D.; Ladkin, A. Smart Technologies for Personalized Experiences: A Case Study in the Hospitality Domain. Electron. Mark. 2015, 25, 243-254. [CrossRef]

27. Lancaster, K. A new approach to consumer theory. J. Political Econ. 1966, 74, 132-157. [CrossRef]

28. McFadden, D. Conditional Logit Analysis of Qualitative Choice Behavior. In Frontiers in Econometrics; Zarembka, P., Ed.; Academic Press: New York, NY, USA, 1974; pp. 105-142.

29. McFadden, D. The Choice Theory Approach to Market Research. Mark. Sci. 1986, 5, 275-297. [CrossRef]

30. Bennett, J.W. Some Fundamentals of Environmental Choice Modelling; Choice Modelling Reports, Research Report No. 11; The University of New South Wales: Canberra, Australia, 1999.

31. Shanahan, M.; Larance, B.; Nielsen, S.; Cohen, M.; Schaffer, M.; Campbell, G. A protocol for a discrete choice experiment: Understanding patient medicine preferences for managing chronic noncancer pain. Br. Med. J. 2019, 9. [CrossRef]

32. Dolnicar, S.; Otter, T. Which Hotel Attributes Matter? A Review of Previous and a Framework for Future Research. In Proceedings of the 9th Annual Conference of the Asia Pacific Tourism Association (APTA); Griffin, T., Harris, R., Eds.; University of Technology Sydney: Sydney, Australia, 2003; pp. 176-188. Available online: https:/citeseerx.ist.psu.edu/viewdoc/download?doi=10.1.1.303.8284\&rep=rep1\&type=pdf (accessed on 28 September 2020).

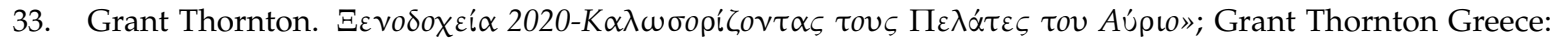
Athens, Greece, 2016. (In Greek)

34. Millar, M.; Baloglu, S. Hotel Guests' Preferences for Green Guest Room Attributes. Cornell Hosp. Q. 2011, 52, 302-311. [CrossRef]

35. Holcomb, J.; Upchurch, R.; Okumus, F. Corporate Social Responsibility: What Are Top Hotel Companies Reporting? Int. J. Contemp. Hosp. Manag. 2007, 19, 461-475. [CrossRef]

36. Hsieh, Y. Hotel companies' environmental policies and practices: A content analysis of their web pages. Int. J. Contemp. Hosp. Manag. 2012, 24, 97-121. [CrossRef]

37. Kasim, A. The Need for Environmental and Social Responsibility in the Tourism Industry. Int. J. Hosp. Environ. Manag. 2006, 7, 1-22. [CrossRef] 
38. Gössling, S. Tourism's contribution to global environmental change: Space, energy, disease and water. In Aspects of Tourism: Tourism, Recreation and Climate Change; Hall, C., Higham, J., Eds.; Channel View Publications: Clevedon, UK, 2005; Chapter 20; pp. 286-295.

39. Epp, C.; Decras, N.; Tondy, G.; Capaccioli, S.; Ribiero, J.F. Policy Initiative to Overcome Water Competition between Agriculture and Tourism. Undated. Available online: www.medwater.de/pdf/Crete_Conference_ abstract.pdf (accessed on 31 August 1999).

40. Hillary, R. Evaluation of Study Reports on the Barriers, Opportunities and Drivers for Small and Medium Size Enterprises in the Adoption of EMS; Network for Environmental Management and Auditing; Crown Publications: London, UK, 1999.

41. Gössling, S.; Peeters, P.; Hall, M.; Ceron, J.P.; Dubois, G.; Lehman, L.; Scott, D. Tourism and Water Use: Supply Demand and Security. An International Review. Tour. Manag. 2012, 33, 1-15. [CrossRef]

42. Utting, P. Business Responsibility for Sustainable Development; Occasional Paper, No. 2; United Nations Research Institute for Social Development: Geneva, Switzerland, 2000.

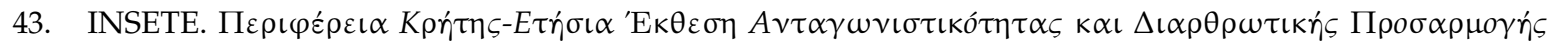

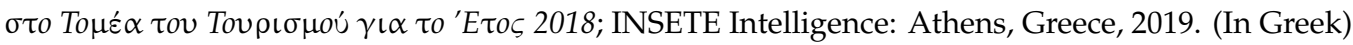

44. Zientara, P.; Bohdanowicz-Godfrey, P.; Whitley, C.; Maciejewski, G. A Case Study of LightStay (2010-2017)—Hilton's Corporate Responsibility Management System. Energies 2020, 13, 2303. [CrossRef]

45. Reed Johnson, F.; Lancsar, E.; Marshall, D.; Kilambi, V.; Mühlbacher, A.; Regier, D.; Bresnahan, B.; Kanninen, B.; Bridges, J. Constructing experimental designs for discrete-choice experiments: Report of the ISPOR Conjoint Analysis Experimental Design Good Research Practices Task Force. Value Health 2013, 16, 3-13. [CrossRef]

46. Hensher, D.; Rose, J.; Greene, W. Applied Choice Analysis Primer; Cambridge University Press: Cambridge, UK, 2005.

47. Tinelli, M. Applying Discrete Choice Experiments in Social Care Research; NIHR School for Social Care Research Methods Review 19; London School of Economics and Political Science: London, UK, 2016.

48. Kontogianni, A.; Kabassi, K.; Alepis, E. Designing a smart tourism mobile application: User modeling through social networks' user implicit data. In Proceedings of the Social informatics-10th international conference proceedings (Part II), St. Petersburg, Russia, 25-28 September 2018.

49. Atembie, R. Examining Tourists' Mobile Experiences in using Online Booking Platforms. In Proceedings of the 2016 TTRA International Conference, Ljubljana, Slovenia, 24-26 January 2007.

50. Randhawa, P.; Kim, M.; Cichy, R. Service Innovations: What the Managers Believe and What the Customers Say. J. Hosp. Mark. Manag. 2017, 26, 186-206. [CrossRef]

51. Victorino, L.; Verma, R.; Plaschka, G.; Chekitan, D. Service Innovation and Customer Choices in the Hospitality Industry. Manag. Serv. Qual. 2005, 15, 555-576. [CrossRef]

52. Kang, K.; Stein, L.; Heo, C.; Lee, S. Consumers' Willingness to Pay for Green Initiatives of the Hotel Industry. Int. J. Hosp. Manag. 2012, 31, 564-572. [CrossRef]

53. Tsagarakis, K.; Bounialetou, F.; Gillas, K.; Profylienou, M.; Pollaki, A.; Zografakis, N. Tourists' Attitudes for Selecting Accommodation with Investments in Renewable Energy and Energy Saving Systems. Renew. Sustain. Energy Rev. 2011, 15, 1335-1342. [CrossRef]

54. Robinot, E.; Giannelloni, J. Do hotels' "green" attributes contribute to customer satisfaction? J. Serv. Mark. 2010, 24, 157-169. [CrossRef]

55. Hotel Energy Solutions. Analysis of Energy Use by European Hotels: Online Survey and Desk Research; Hotel Energy Solutions Project Publication, World Tourism Organization: Madrid, Spain, 2011.

56. Dos Santos, A.; Mexas, M.P.; Meirino, M.J. Sustainability and Hotel Business: Criteria for Holistic, integrated and Participative Development. J. Clean. Prod. 2017, 142, 217-224. [CrossRef]

57. Carlucci, D.; Breunig, K.J.; Aas, T.H.; Hydle, K.M. Incentives and performance measures for open innovation practices. Meas. Bus. Excell. 2014, 18, 45-54.

58. Green Prices, Green Energy and Quality Labeling. Re-Focus, January-February 2001. pp. 42-44. Available online: www.re-focus.net (accessed on 10 September 2019).

59. Erdogan, N.; Baris, E. Environmental protection programs and conservation practices of hotels in Ankara, Turkey. Tour. Manag. 2007, 28, 604-614. [CrossRef]

60. Radwan, H.R.; Jones, E.; Minoli, D. Solid waste management in small hotels: A comparison of green and non-green small hotels in Wales. J. Sustain. Tour. 2012, 20, 533-550. [CrossRef] 
61. Kasim, A.; Gursoy, D.; Okumus, F.; Wong, D. The Importance of Water Management in Hotels: A Framework for Sustainability through Innovation. J. Sustain. Tour. 2014, 22, 1090-1107. [CrossRef]

62. Berezan, O.; Raab, C.; Yoo, M.; Love, C. Sustainable hotel practices and nationality: The impact on guest satisfaction and guest intention to return. Int. J. Hosp. Manag. 2013, 34, 227-233. [CrossRef]

(C) 2020 by the authors. Licensee MDPI, Basel, Switzerland. This article is an open access article distributed under the terms and conditions of the Creative Commons Attribution (CC BY) license (http://creativecommons.org/licenses/by/4.0/). 